\title{
微小き裂成長の下限界応力拡大係数の統一化に関する一考察
}

\author{
安藤 柱 ${ }^{*}$, 笛木隆太郎 ${ }^{* *}$, 南起祐 ${ }^{* * *}$, 松井勝幸 ${ }^{* * * *}$, 高橋宏治 ${ }^{* *}$

\section{A Study on the Unification of the Threshold Stress Intensity Factor for Micro Crack Growth}

\author{
Kotoji ANDO, Ryutaro FUEKI, Ki Woo NAM, Katsuyuki MATSUI \\ and Koji TAKAHASHI
}

\begin{abstract}
When the crack length is larger than a certain size, the maximum stress intensity factor $\left(K_{\max }\right)$ is used to explain the occurrence condition of brittle crack, and the limit condition of hydrogen assisted and stress corrosion crack propagation. Also, the fatigue crack can be explained by the stress intensity factor range $(\Delta K)$. However, since the stress intensity factor deals with only linear elastic body, it is necessary for nonlinear range of crack tip to be small enough. It is known that in the case where this condition is not satisfied, the proposition shall be called the micro crack problem, and it is known that the crack size is smaller than the threshold value of the long crack. The purpose of this study is to unify the microcracking problems of various fracture modes. The crack length which is dependent on the threshold value can be explained by one concept considering the fact that the nonlinear region size of the crack tip is constant regardless of the crack length. In this paper, unified equation for micro crack problem to four kinds of cracks was proposed.
\end{abstract}

Key Words : Micro Crack Growth, Threshold Stress Intensity Factor, Fatigue Crack, Hydrogen Embrittle Crack, Stress Corrosion Crack

\section{1. 緒 言}

近年の線形破壊力学の進歩により, き裂問題のかなり の事象を応力拡大係数 $(K$ 值) で定量的に取り扱えるように なった。すなわち, ぜい性き裂発生条件 ${ }^{1,2}$, , 疲労き裂3), 水素ぜい性き裂4) 抢よび応力腐食割れ ${ }^{5), 6)}$ などのき裂成長 速度は解明された。 また, それらの知見を活用して, 久陥 評価を行う規格が制定され，実用に供されている(5) 99.

しかし, 線形破壊力学では, 等方・均質・弾性体を仮定 しているために，き裂先端部に形成される非線形領域の寸 法がき裂長さに比べて，十分小さくないときには，長いき 裂の下限界 $K$ 值に比し，それよりかなり小さい $K$ 值 (疲労の 場合には $\Delta K$ ) でき裂の成長が起こる ${ }^{1), 10)}$. 非線形領域の例 としては, 金属では塑性域や粗大結晶粒が, セラミックス では, ごく微細なき裂の分散域や結晶粒の影響が指摘され ている $\left.{ }^{11)} 13\right)$. この問題は, 微小き裂の下限界值問題と呼 ばれており，金属の疲労限度の場合には，早くからその特 性がほぼ解明され，有意義な提案が行われている10),14) 17). 金属のぜい性破壊に関しては, 疲労限度に比べてやや遅れ たが, 微小き裂の下限界值問題に関して, 非線形領域の影 響を正視した先駆的研究が抢こなわれている11.
一方, 構造用セラミックスは, 典型的なぜい性材料と考 えられていたが，微小き裂に対しては，平面ひずみ破壞じ ん性值 $K_{\mathrm{IC}}$ が適用できないことが示されている ${ }^{11,18), 19)}$ 。そ の結果を勘案し，プロセスゾーン破壊基準が提案され，そ の特性を良く説明できることが示されている ${ }^{11,12)}$.

上述のごとく, 疲労限度やぜい性破壊の微小き裂の下限 界値問題に関しては, 多くの研究が実施10) 12), 14) 17) され ているが，ぜい性破壊，疲労破壊，水素ぜい性及び応力腐 食割れなどのき裂を統一した考えによる微小き裂問題の解 明は実施されていない，そこで，筆者らは，ぜい性破壊， 疲労破壞，水素ぜい性及び応力腐食割れ等のき裂を統一的 に取り扱える微小き裂の下限界值問題を検討することとし た.

\section{2. ぜい性破壊, 水素ぜい性及び応力腐食割れの微 小き裂の下限界値問題}

\section{1 き裂先端部に形成される塑性域寸法}

Fig. 1 のごとく，無限板に長さ $2 c_{0}$ のき裂が存在し，無限 遠で $\sigma_{\mathrm{T}}$ なる引張応力を受ける場合に形成される塑性域寸法 Ry はDugdaleモデル20)により，下記の(1)式で与えられる. 
$R_{y}=c_{0}\left\{\sec \left(\frac{\pi \sigma_{T}}{2 \sigma_{y}}\right)-1\right\}$

ここで， $\sigma_{\mathrm{y}}$ は降伏応力である

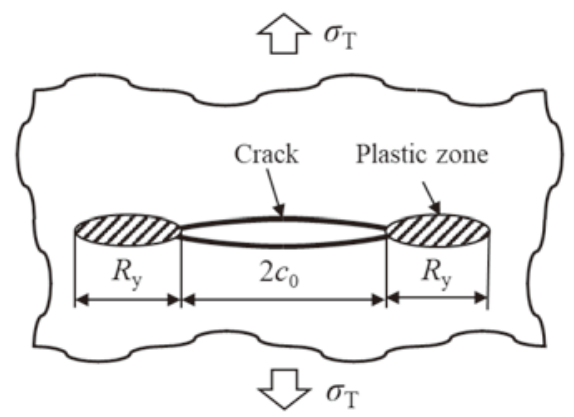

Fig. 1 Schematic illustration of plastic zone of crack tip.

\section{2 ぜい性き裂の場合}

ぜい性破壊に関する微小き裂問題は, 最初Milneら ${ }^{11} に$ より発表された。彼らは，き裂長さによらず，き裂先端部 に形成された塑性域の寸法が材料及びその板厚や試験温度 等には依存するが，き裂長さによらない固有值 $R_{\mathrm{yBC}} に$ 達し た時にぜい性破壞が発生すると仮定した。この仮定により (1)式は下記の (2)式のように表される.

$$
R_{\mathrm{yBC}}=c_{0}\left\{\sec \left(\frac{\pi \sigma_{\mathrm{BC}}}{2 \sigma_{\mathrm{y}}}\right)-1\right\}
$$

ここで， $\sigma_{\mathrm{BC}}$ はき裂材のぜい性破壊発生応力である. 式の右辺の第一項は, き裂が十分長い時には, $\left(\pi \sigma_{\mathrm{BC}} / 2 \sigma_{\mathrm{y}}\right)$ は十分小さいので,

$$
c_{0}\left\{\sec \left(\frac{\pi \sigma_{\mathrm{BC}}}{2 \sigma_{\mathrm{y}}}\right)\right\}=c_{0}\left\{1+\frac{1}{2}\left(\frac{\pi \sigma_{\mathrm{BC}}}{2 \sigma_{\mathrm{y}}}\right)^{2}\right\}
$$

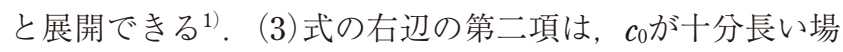
合には，(4)式のごとく置き，(3)式の右辺の第二項に代入 することにより (5)式が得られる ${ }^{1)}$.

$$
K_{\mathrm{BC}(\infty)}=\sigma_{\mathrm{BC}} \sqrt{\pi c_{0}}
$$

ここで, $K_{\mathrm{BC}(\infty)}$ は, 板厚が同じでき裂が十分長いときの 破壞じん性值であり, 平面ひずみ破壞じん性值 $K_{\mathrm{IC}}$ である 必要性はない。

$$
c_{0}\left\{\sec \left(\frac{\pi \sigma_{B C}}{2 \sigma_{y}}\right)-1\right\}=\frac{\pi}{8}\left(\frac{K_{\mathrm{BC}(\infty)}}{\sigma_{y}}\right)^{2}
$$

(5) 式の右辺の各值は特性值であるから, 破壊じん性値 $K_{\mathrm{BC}}$ のき裂長さ依存性は, 式 (5)より求めた $c_{0}$ と $\sigma_{\mathrm{BC}}$ との関係 を下記の (6)式に代入することにより求めることができる.

$$
K_{\mathrm{BC}}=\sigma_{\mathrm{BC}} \sqrt{\pi c_{0}}
$$

ここで，K $K_{\mathrm{BC}}$ はき裂長さに依存し，き裂が長くなるにつ れて増大する。そその飽和值が $K_{\mathrm{BC}(\infty)}$ である。 $K_{\mathrm{BC}(\infty)}$ に達す るときのき裂長さは，き裂形状にかなり依存する。また， 材料の $K_{\mathrm{BC}(\infty)}$ が大きく, 降伏応力が低いほど, $K_{\mathrm{BC}}$ が飽和 するき裂長さは長くなる。（6)式で得られた $c_{0}$ と $\sigma_{\mathrm{BC}}$ との関 係は, 金属のぜい性破壊やセラミックスのぜい性破壊に対 して精度良く成立することが知られている1,12),13)．ただし， セラミックスの場合には, 降伏応力 $\sigma_{\mathrm{y}}$ の代わりに平滑材の 破壊応力 $\sigma_{0}$ を代入することが必要である ${ }^{12), 13)}$.

\section{3 水素ぜい性き裂及び応力腐食割れの場合}

水素ぜい性き裂及び応力腐食割れの場合にも，き裂先端 部に形成された塑性域 $R_{\mathrm{y}}$ の寸法は, 材料, 試験温度, 水素 濃度，あるいは腐食性溶液などには依存するが，き裂長さ によらない固有值(水素ぜい性の場合には $R_{\mathrm{yHC}}$, 応力腐食 割れの場合には $\left.R_{\mathrm{y} S \mathrm{C}}\right)$ に達したときに，それぞれに対応し たき裂が成長すると仮定する。この仮定により，(2)式か ら（6)式に执いて，次のような置き換えを行うことにより， 微小き裂材の下限界応力拡大係数とき裂長さとの関係が評 価可能となる。

A） 水素ぜい性き裂の場合

$R_{\mathrm{yBC}} \rightarrow R_{\mathrm{yHC}}, \sigma_{\mathrm{BC}} \rightarrow \sigma_{\mathrm{HC}}, \mathrm{K}_{\mathrm{BC}(\infty)} \rightarrow K_{\mathrm{HC}(\infty)}, K_{\mathrm{BC}} \rightarrow K_{\mathrm{HC}}$

ここで, 各記号の定義は以下のと抢りである.

$R_{\mathrm{yHC}}$ : 水素ぜい性き裂が成長するために最低限必要なき 裂先端部の塑性域寸法

$\sigma_{\mathrm{HC}}$ ：ある長さの水素ぜい性き裂が成長するための下限 界応力

$K_{\mathrm{HC}(\infty)}$ : 充分長い水素ぜい性き裂が成長するための下限 界応力拡大係数

$K_{\mathrm{HC}}$ ：ある長さの水素ぜい性き裂が成長するための下限 界応力拡大係数

B）応力腐食割れの場合

$R_{\mathrm{yBC}} \rightarrow R_{\mathrm{ySC}}, \sigma_{\mathrm{BC}} \rightarrow \sigma_{\mathrm{SC}}, K_{\mathrm{BC}(\infty)} \rightarrow K_{\mathrm{SC}(\infty)}, K_{\mathrm{BC}} \rightarrow K_{\mathrm{SC}}$

ここで，各記号の定義は以下のと抢りである。

$R_{\mathrm{ySC}}$ : 応力腐食割れが成長するために最低限必要なき裂 先端部の塑性域寸法

$\sigma_{\mathrm{Sc}}$ ：ある長さの応力腐食割れが成長するための下限界 応力

$K_{\mathrm{SC}(\infty)}$ ：充分長い応力腐食割れが成長するための下限界 応力拡大係数

$K_{\mathrm{SC}}$ ：ある長さの応力腐食割れが成長するための下限界 応力拡大係数

\section{3. 微小な疲労き裂の下限界応力拡大係数範囲 3.1 疲労破壊のプロセスと平滑材の疲労限度における塑 性変形について}

平滑材の疲労限度に関しては, 非常に多くの報告がある. 
疲労破壊は大部分の金属系材料では，次のような 7 段階の プロセスを経て破壊に至ることが知られている ${ }^{21)}$ 。その模 式図をFig. 2に示す. 疲労破壊に至るまでの 7 段階のプロ セスを以下に述べる

(1) 通常, 平滑材の疲労限度における最大引張応力 $\sigma_{\mathrm{w}}$ は, 材料の降伏応力 $\sigma_{\mathrm{y}}$ より低いが, 繰返し効果により多く の結晶粒にすべり帯が形成される。

(2) すべり带が活湀化して, 入込みや突出しが形成される. もし, 同一のすべり帯が引張側と除荷側で活動すれば, 入込みや突出しは，あまり形成されないはずである. したがって，あるすべり帯は，引張側で，また別のあ るすべり帯は除荷側で活動すると考えられる。

(3) 繰返しのせん断応力が入込み部で集中することによ り，せん断型き裂が形成される。

(4) 上記(3)のき裂が1〜2結晶粒伝播し，停留する

(5) 上記(4)のせん断型き裂が，引張型き裂に遷移する.

(6) 上記(5)引張型き裂が, Stage IIのき裂として伝播す る.

(7) 最終破壊.

しかし，疲労限度を示した材料では，上記のプロセスが 第 4 段階までで停止し，せん断型き裂が残留する場合が多 い17)。このき裂はStage I の停留き裂21)と呼ばれている.

平滑材の疲労破壊は上記のような 7 段階に分類されるこ とが多いが，そのうちの第 2 段階では，すべり帯が活発に 活動し, 入达みや突出しを形成する応力変動幅 $\Delta \sigma_{\mathrm{w}}$ が作用 している段階である。つまり，この段階では微視的にかな りの塑性変形が形成されるため, その領域における最大引 張応力は $\sigma_{\max }$ で一定であると考えることができる. 以後, この值を疲労降伏応力と呼ぶ。ここで, 応力比 $R$ における 疲労降伏応力を $\sigma_{\mathrm{wm}}^{\mathrm{R}}$ とすると, $\sigma_{\mathrm{wm}}^{\mathrm{R}}$ と応力比 $R$ における平 滑材の疲労限度の応力変動幅 $\Delta \sigma_{\mathrm{w}}^{\mathrm{R}}$ の関係は, (7) 式で表され る.

$$
\sigma_{\mathrm{wm}}^{\mathrm{R}}=\frac{\Delta \sigma_{\mathrm{w}}^{\mathrm{R}}}{(1-R)}
$$

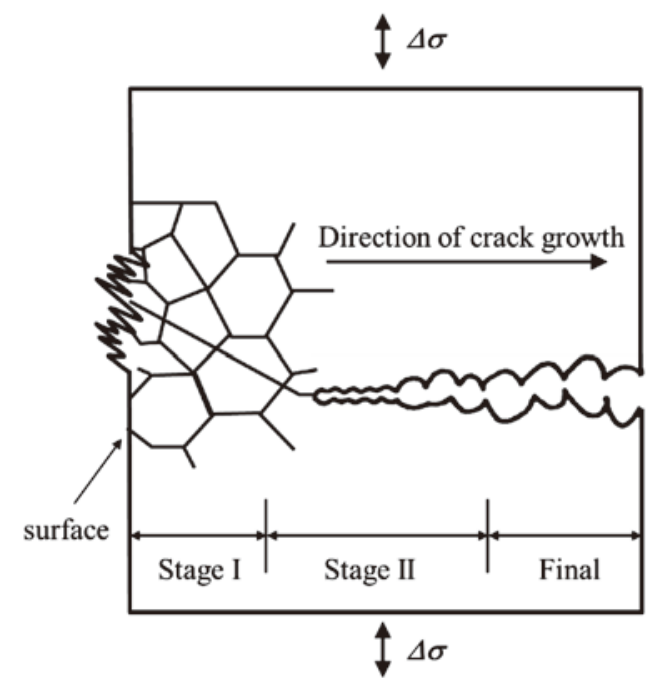

Fig. 2 Schematic illustration of fatigue fracture process.

\section{2 無限板中の微小な疲労き裂の下限界応力拡大係数範} 囲について

何らかの要因で生じた予き裂が, 疲労により停留するか 進展するかの限界の予き裂先端では，き裂長さによらない 繰返し応力による塑性域 $R_{\mathrm{yFC}}$ が形成されるものと仮定する.

応力比 $R$ における疲労限度で形成される $R_{\mathrm{yFC}}$ は, Dugdale による(1)式より，下記の (8) 式で与えられる。（8)式中の 最大応力 $\sigma_{\mathrm{wm}}^{\mathrm{R}}$ は, 3.1 節の考察より, 平滑材の疲労降伏応 力として与えられるものである.

$$
R_{\mathrm{yFC}}=c_{0}\left\{\sec \left(\frac{\pi \sigma_{\mathrm{wcm}}^{\mathrm{R}}}{2 \sigma_{\mathrm{wm}}^{\mathrm{R}}}\right)-1\right\}
$$

ここで， $c_{0}$ は無限板中に存在する任意の貫通き裂長さの 半長, $\sigma_{\mathrm{wcm}}^{\mathrm{R}}$ はき裂長さが $c_{0}$ のときの応力比 $R て ゙ の$ 疲労限度 における最大応力であり, その疲労限度における応力変動 幅 $\Delta \sigma_{\mathrm{wc}}^{\mathrm{R}}$ を用いて，下記の $(9)$ 式で表される。

$$
\sigma_{\mathrm{wcm}}^{\mathrm{R}}=\frac{\Delta \sigma_{\mathrm{wc}}^{\mathrm{R}}}{(1-R)}
$$

(8) 式のsec項は, 予き裂が十分長い場合には, $\pi \sigma_{\mathrm{wcm}}^{\mathrm{R}} /$ $\left.2 \sigma_{\mathrm{wm}}^{\mathrm{R}}\right)$ が十分小さいので，(3)式と同様に第2項までの級数 展開で十分に近似できる。よって，(8) 式は下記の(10)式 で表せる。

$$
c_{0}\left\{\sec \left(\frac{\pi \sigma_{\mathrm{wcm}}^{\mathrm{R}}}{2 \sigma_{\mathrm{wm}}^{\mathrm{R}}}\right)-1\right\}=c_{0}\left\{\frac{1}{2}\left(\frac{\pi \sigma_{\mathrm{wcm}}^{\mathrm{R}}}{2 \sigma_{\mathrm{wm}}^{\mathrm{R}}}\right)^{2}\right\}
$$

（10）式の右辺は,

$$
c_{0}\left\{\frac{1}{2}\left(\frac{\pi \sigma_{\mathrm{wcm}}^{\mathrm{R}}}{2 \sigma_{\mathrm{wm}}^{\mathrm{R}}}\right)^{2}\right\}=\frac{\pi}{8}\left(\frac{\sigma_{\mathrm{wcm}}^{\mathrm{R}} \sqrt{\pi c_{0}}}{\sigma_{\mathrm{wm}}^{\mathrm{R}}}\right)^{2}
$$

と整理できる。（7），(9)，(10)，(11)式より，下記の (12) 式が得られる。

$$
R_{\mathrm{yFC}}=c_{0}\left[\sec \left\{\frac{\pi \Delta \sigma_{\mathrm{wc}}^{\mathrm{R}}}{2 \Delta \sigma_{\mathrm{w}}^{\mathrm{R}}}\right\}-1\right]=\frac{\pi}{8}\left\{\frac{\Delta \sigma_{\mathrm{wc}}^{\mathrm{R}} \sqrt{\pi c_{0}}}{\Delta \sigma_{\mathrm{w}}^{\mathrm{R}}}\right\}^{2}
$$

ここで，無限板中に長さ $2 c_{0}$ の十分に長い貫通き裂が存 在する場合の下限界応力拡大係数範囲を $\Delta K_{\mathrm{th}(\infty)}^{\mathrm{R}}$ とする と, $\Delta K_{\mathrm{th}(\infty)}^{\mathrm{R}}$ は応力比 $R$ での疲労限度における応力変動幅 $\Delta \sigma_{\mathrm{wc}_{0}}^{\mathrm{R}}$ を用いて

$$
\Delta K_{\mathrm{th}(\infty)}^{\mathrm{R}}=\Delta \sigma_{\mathrm{wc}_{0}}^{\mathrm{R}} \sqrt{\pi c_{0}}
$$

と表せる。（12)式について，(13)式より,以下の関係が成り 立つ。

$$
c_{0}\left\{\sec \left(\frac{\pi \Delta \sigma_{\mathrm{wc}}^{\mathrm{R}}}{2 \Delta \sigma_{\mathrm{w}}^{\mathrm{R}}}\right)-1\right\}=\frac{\pi}{8}\left(\frac{\Delta K_{\mathrm{th}(\infty)}^{\mathrm{R}}}{\Delta \sigma_{\mathrm{w}}^{\mathrm{R}}}\right)^{2}
$$


(14) 式の右辺は定数であるから, 第二項より $c_{0}$ と $\Delta \sigma_{\mathrm{wc}}^{\mathrm{R}}$ と の関係を求めることができる。ここで，無限板中に任意の 長さ $2 c_{0}$ の貫通き裂が存在する場合の下限界応力拡大係数 範囲 $\Delta K_{\mathrm{th}}^{\mathrm{R}}$ は下式で評価できる.

$$
\Delta K_{\mathrm{th}}^{\mathrm{R}}=\Delta \sigma_{\mathrm{wc}}^{\mathrm{R}} \sqrt{\pi c_{0}}
$$

(15)式を変形すると，

$$
\Delta \sigma_{\mathrm{wc}}^{\mathrm{R}}=\frac{\Delta K_{\mathrm{th}}^{\mathrm{R}}}{\sqrt{\pi c_{0}}}
$$

（16)式を(14)式に代入して (14) 式を整理すると，下記の (17) 式のような下限界応力拡大係数範囲のき裂長さ依存性 評価式が得られる.

$$
\Delta K_{\mathrm{th}}^{\mathrm{R}}=2 \Delta \sigma_{\mathrm{w}}^{\mathrm{R}} \sqrt{\frac{c}{\pi}} \cos ^{-1}\left[\left\{\frac{\pi}{8 c}\left(\frac{\Delta K_{\mathrm{th}(\infty)}^{\mathrm{R}}}{\Delta \sigma_{\mathrm{w}}^{\mathrm{R}}}\right)^{2}+1\right\}^{-1}\right]
$$

\section{3 無限板中の貫通き裂と有限板中の半楕円表面き裂の 破壊力学的関係}

3.2節で導出した(17) 式は無限板中に存在する貫通き裂 に対する下限界応力拡大係数範囲の評価式である。ここで は，(17)式を有限板中に存在する半楕円表面き裂に適用す る方法について述べる.

無限板中の長さ $2 c_{0}$ の貫通き裂が一様な引張応力 $\sigma_{\mathrm{T}}$ を受 けるときの応力拡大係数 $K$ は下式で与えられる.

$$
K=\sigma_{\mathrm{T}} \sqrt{\pi c_{0}}
$$

一方, 有限板中の半楕円表面き裂のKはNewman-Rajuの 式22)により評価することが可能である. Fig. 3のように, 有限板中の長さ $2 c$, 深さ $a$ の半楕円表面き裂が一様な引張 応力 $\sigma_{\mathrm{T}}$ を受けるときの応力拡大係数 $K$ は下記の (19) 式で与 えられる。

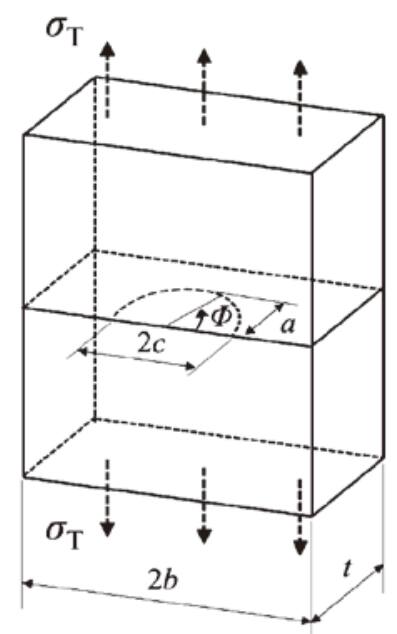

Fig. 3 Schematic illustration of a finite plate containing a semi-circular crack.

$$
K=\frac{F\left(\frac{a}{t}, \frac{a}{c}, \frac{c}{b}, \phi\right)}{\sqrt{Q\left(\frac{a}{c}\right)}} \sigma_{\mathrm{T}} \sqrt{\pi a}=\alpha \sigma_{\mathrm{T}} \sqrt{\pi a}
$$

ここで, $F$ 及びQは形状補正関数, $t$ は有限板の厚さ, $b$ は有限板の幅の半長, $\phi$ は $K$ を評価する半楕円表面き裂前 縁の角度である。（19)式の第三項では形状補正関数をまと めて $a$ と表記している. 有限板中の半楕円表面き裂が応力 を受ける場合, 同一の応力において同一のKを与える無限 板中の貫通き裂長さを等価き裂長さ $c_{\mathrm{e}}$ とすと，(18)式な らびに(19)式より，下記の (20) 式が成り立つ.

$$
K=\sigma_{\mathrm{T}} \sqrt{\pi c_{\mathrm{e}}}=\alpha \sigma_{\mathrm{T}} \sqrt{\pi a}
$$

(20)式を整理することにより， $c_{\mathrm{e}}$ と $a$ の関係は下式で与 えられる。

$$
\sqrt{c_{\mathrm{e}}}=\alpha \sqrt{a}
$$

したがって，有限板中の半楕円表面き裂に対する $\Delta K_{\text {th }}$ のき裂寸法依存性は(17) 式のcに(21) 式で与えられる $c_{\mathrm{e}}$ を 代入することにより，下記の $(22)$ 式で評価できる.

$$
\Delta K_{\mathrm{th}}^{\mathrm{R}}=2 \alpha \Delta \sigma_{\mathrm{w}}^{\mathrm{R}} \sqrt{\frac{a}{\pi}} \cos ^{-1}\left[\left\{\frac{\pi}{8 \alpha^{2} a}\left(\frac{\Delta K_{\mathrm{th}(\infty)}^{\mathrm{R}}}{\Delta \sigma_{\mathrm{w}}^{\mathrm{R}}}\right)^{2}+1\right\}^{-1}\right]
$$

また, 有限板中の半楕円表面き裂が曲げ応力 $\sigma_{\mathrm{B}}$ を受け る場合, 応力拡大係数 $K$ は,

$$
K=\frac{H\left(\frac{a}{t}, \frac{a}{c}, \frac{c}{b}, \phi\right) F\left(\frac{a}{t}, \frac{a}{c}, \frac{c}{b}, \phi\right)}{\sqrt{Q\left(\frac{a}{c}\right)}} \sigma_{\mathrm{B}} \sqrt{\pi a}=\beta \sigma_{\mathrm{B}} \sqrt{\pi a} \ldots
$$

で与えられる。ここで，Hは曲げ応力に関する補正関数， $\beta$ は補正関数をまとめた形状補正係数である. (23) 式より, (19)式の第三項における $\alpha$ を $\beta$ に， $\sigma_{\mathrm{T}}$ を $\sigma_{\mathrm{B}}$ に置き換えて 考えると, 曲げ応力を受けるときの $\Delta K_{\mathrm{th}}$ のき裂寸法依存 性は下式により評価できる。

$$
\Delta K_{\mathrm{th}}^{\mathrm{R}}=2 \beta \Delta \sigma_{\mathrm{w}}^{\mathrm{R}} \sqrt{\frac{a}{\pi}} \cos ^{-1}\left[\left\{\frac{\pi}{8 \beta^{2} a}\left(\frac{\Delta K_{\mathrm{th}(\infty)}^{\mathrm{R}}}{\Delta \sigma_{\mathrm{w}}^{\mathrm{R}}}\right)^{2}+1\right\}^{-1}\right]
$$

$a$ 及び $\beta$ は $\phi$ 関数であり，Kを評価するき裂前縁の角 度によってKの評価值が変化するが，（15）式について半楕 円き裂の場合を考えると， $\Delta K_{\text {th }}$ を決定づけるのは $K$ の最大 值であるといえる。（19)式及び $(23)$ 式より，Kが最大とな るのは $\alpha$ 及び $\beta$ が最大となるときであるから，(22)式及び (24) 式にはそれぞれ $\alpha, \beta$ の最大值を代入すればよい. 


\section{4 既存の評価式との比較}

微小き裂問題は, 小規模非線形領域の仮定が成立し ない問題なので, 本来は非線形問題である。ところが, Haddad ${ }^{14)}$ は, 高度な工学的感性により, き裂長さlに微 小なき裂長さ $l_{0}$ を加えて $l+l_{0}$ とすることにより， $\Delta K_{\mathrm{th}}$ のき 裂長さ依存性に関する妥当な評価式を誘導した。形状補正 係数を $\gamma$ とし, 応力拡大係数範囲の計算を $\Delta K=\gamma \Delta \sigma \sqrt{\pi l}$ と すると, Haddadらが誘導した式は(25) 式及び(26)式のよ うに表せる。

$$
\begin{gathered}
\Delta \sigma_{\mathrm{wl}}^{\mathrm{R}}=\frac{\Delta K_{\mathrm{th}(\infty)}^{\mathrm{R}}}{\gamma \sqrt{\pi\left(l+l_{0}\right)}} \\
l_{0}=\frac{1}{\pi}\left(\frac{\Delta K_{\mathrm{th}(\infty)}^{\mathrm{R}}}{\gamma \Delta \sigma_{\mathrm{w}}^{\mathrm{R}}}\right)^{2}
\end{gathered}
$$

ここで, $\Delta \sigma_{\mathrm{wl}}^{\mathrm{R}}$ はき裂長さがlのときの応力比 $R$ での疲労 限度に㧍ける応力変動幅である.

丹下ら ${ }^{17)}$ は，(25) 式に(26) 式を代入し, Haddadらの提 案式から $l_{0}$ を消去することにより，より便利な $(27)$ 式を誘 導している。

$$
\Delta K_{\mathrm{th}}^{\mathrm{R}}=\gamma \Delta \sigma_{\mathrm{wl}}^{\mathrm{R}} \sqrt{\pi l}=\frac{\Delta K_{\mathrm{th}(\infty)}^{\mathrm{R}} \sqrt{l}}{\left\{l+\frac{1}{\pi}\left(\frac{\Delta K_{\mathrm{th}(\infty)}^{\mathrm{R}}}{\gamma \Delta \sigma_{\mathrm{w}}^{\mathrm{R}}}\right)^{2}\right\}^{0.5}}
$$

深さ $a$ の半楕円表面き裂が存在する有限板に対して $(27)$ 式により $\Delta K_{\mathrm{th}}^{\mathrm{R}}$ 評価する場合は，(27)式の $l$ に $a$ を代入し, $\gamma$ には単軸引張応力を受ける場合は (19)式の $\alpha$ を, 曲げ応 力を受ける場合は, $(23)$ 式の $\beta$ を代入すればよい.

著者らが過去に実施したばね鋼SUP9Aの実験データ23)を 使用し，本論文で提案した $(24)$ 式及び丹下らが導出した

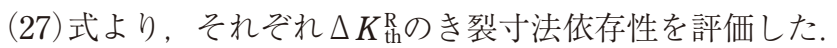
評価に使用した実験データの詳細はTable 1を参照された い.ここで, $\Delta \sigma_{\mathrm{w}}^{0} と \Delta K_{\mathrm{th}(\infty)}^{0}$ は, それぞれ応力比が零の場 合の疲労限度に扮ける応力変動幅と下限界応力拡大係数範 囲の飽和值である。

$\Delta K_{\mathrm{th}}^{\mathrm{R}}$ のき裂寸法依存性の評価結果をFig. 4に示す。 $\Delta K_{\mathrm{th}}^{\mathrm{R}}$ はき裂長さに依存し, き裂が長くなるにつれて増大 する，その飽和值が $\Delta K_{\mathrm{th}}^{\mathrm{R}}(\infty)$ である、 $\Delta K_{\mathrm{th}}^{\mathrm{R}}(\infty)$ に達するとき のき裂長さは，き裂形状にかなり依存いする。 また，材料

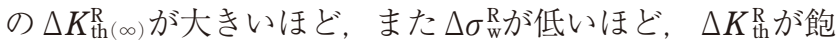
和するき裂長さは長くなる。 ちなみに, 後のFig. 4の場合

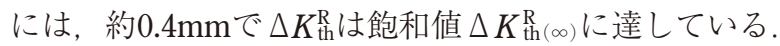

Fig. 4より，両式で得られた $\Delta K_{\mathrm{th}}^{\mathrm{R}}$ のき裂寸法依存性は極 めて良く一致していることがわかる。ここに示さない場合 についても多くの比較を実施したが，やはり本論文の式と 丹下らの式は極めて良い一致を示していた.この結果から， Haddadの論文に記されている微小き裂材の疲労限度デー ターは，本論文の式でも正しく評価できるといえる，本論
Table 1 Experimental data for evaluation of $\Delta K_{\mathrm{th}}^{\mathrm{R} 23)}$.

\begin{tabular}{|c|c|c|c|c|c|}
\hline $\begin{array}{c}b \\
{[\mathrm{~mm}]}\end{array}$ & $\begin{array}{c}t \\
{[\mathrm{~mm}]}\end{array}$ & $\begin{array}{c}a / c \\
{[-]}\end{array}$ & $\begin{array}{c}R \\
{[-]}\end{array}$ & $\begin{array}{c}\Delta \sigma_{\mathrm{w}}^{0} \\
{[\mathrm{MPa}]}\end{array}$ & $\begin{array}{c}\Delta K_{\mathrm{th}(\infty)}^{0} \\
{\left[\mathrm{MPa} \cdot \mathrm{m}^{1 / 2}\right]}\end{array}$ \\
\hline 10 & 3 & 1 & 0 & 880 & 7.5 \\
\hline
\end{tabular}

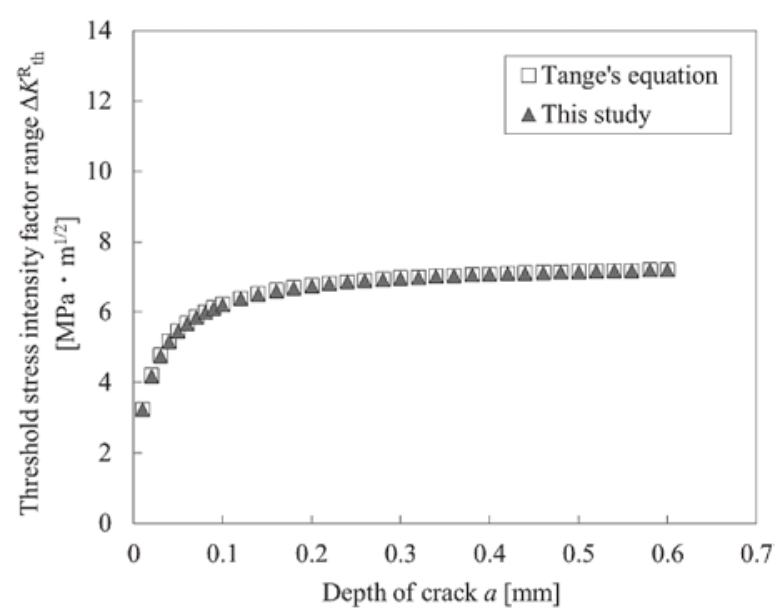

Fig. 4 Evaluation results of $\Delta K_{\mathrm{th}}^{\mathrm{R}}$.

文における(17)式は, 疲労き裂先端の塑性域に着目して誘 導されたものである．基本となる考え方や式の型が全く異 なるにもかかわらず，本論文における(17)式と，Haddad らが提案し丹下らが導出した (27) 式が全く同一の結果を与 えることは興味深いことである。

\section{4. 結 言}

Milneがぜい性破壊で提案した方法を水素ぜい性，応力 腐食割れ，及び疲労限度に応用して，微小き裂問題を統一 的に扱い，かつ各々の現象を一つの考え方で表示できるよ うにするために解析的研究を実施した。そ結果，次のよ うな結論が得られた。

1）Milneの方法を水素ぜい性と応力腐食割れに応用した ところ, 容易に微小き裂の下限界応力拡大係数 $(K)$ 問題を扱う共通の式を誘導できた。

2 ) 疲労限度でのプロセスは7段階に分解されているが, その段階の塑性挙動を検討した，第二段階では，突出 しや入込みが形成されていて, 顕著な塑性挙動を示し ていることから, 疲労限度での最大応力は疲労降伏応 カとして扱えることを明らかにした。

3 ) 疲労限度での最大応力すなわち疲労降伏応力を用い て, 疲労限度での微小き裂の下限界応力拡大係数範囲 $(\Delta K)$ 問題の式を誘導した.

4 ）以上により，ぜい性破壊，水素せい性，応力腐食割れ 及び疲労限度に打ける微小き裂問題を統一化し，一つ の考え方で表記することができた。

5 ）本論文での疲労限度に扔ける微小き裂式とHaddadら が提案し，丹下らが導出した式とでは，基本的な考え 方や式の形は全く異なるものの, Fig. 4に示すように, 下限界応力拡大倸数範囲の值は完全に一致していた. 


\section{参考文献}

1) Milne, I., Ainsworth, R.A., Dowling, A.R. and Stewart, A.T., CEGB Report R/H/R6-Rev. 3 (1986).

2) 秋田好雄, 池田一夫, 岩井宣雄, 日本造船学会論文集, 1964-116 (1964), 136.

3) Paris, P.C. and Erdogan, F., Transaction ASME, J. Basic Engineering, 85-1 (1963), 528.

4) Dunegan, H.L. and Tetelman, A.S., Engineering Fracture Mechanics, 2-4 (1971), 387.

5) ASME B\&PV Code Section XI, 2013, Rules for Inservice Inspection of Nuclear Power Plant Components, American Society of Mechanical Engineers.

6) API 579-1/ ASME FFS-1, 2007, Recommended Practice for Fitness-for-Service, 2nd Edition, American Petroleum Institute.

7）日本溶接協会規格 WES2805 - 1997, 日本溶接協会 (1997).

8）HPISZ 102TR き裂状欠陥評価方法, 日本高圧力技術協 会.

9）日本機械学会, 発電用原子力設備規格 維持規格 (2008 年版, 2009 年追補版含む), JSME S NA1-2008, 2009, 日 本機械学会.

10) Kitagawa, H. and Takahashi, S., Proceedings of the second international conference on mechanical Behavior of materials. Metals Park, OH: ASM, (1976), 627.

11) De los Rios, E.R., Ando, K. and Biddulph, R.H., Fatigue and Fracture of Engineering Materials and Structures. 13-4 (1990), 431.

12）岩佐正明，安藤柱，小倉信和，日本機械学会論文集（A 編), 56-531 (1990), 149 .

13) Ando, K., Kim, B.A., Iwasa, M. and Ogura, N., Fatigue and Fracture of Engineering Materials and Structure, 15-2 (1992), 1.

14) EI Haddad, M.H., Topper, T.H. and Smith, K.N., Engineering Fracture Mechanics, 11 (1979), 573.

15) Frost, N.E. and Dugdale, D.S., Journal of the Mechanics and Physics of Solids, 5-3 (1957) 182.

16) Tanaka, K., Nakai, Y. and Yamasita, M., Internation J. Fracture, 17-5 (1981), 519.

17）丹下彰, 阿久津忠良, 高村典利，ばね論文集，1991-36 (1991), 47.

18）高橋一郎, 宇佐美三郎, 中門公明, 宮田寛, 志田茂, 割業 協会誌, 93-4 (1985), 186.

19）宮田寛，中門公明，木本寛，材料強度学会誌，21-2 (1986), 45.

20) Dugdale, D.S., J. Mechanics and Physics of Solids, 8-2 (1960), 100.

21) Forsyth, P.J.E., Acta. Metallurgical, 11-7 (1963),703.

22) Newman.Jr. J.C., Raju, I.S., Engineering Fracture Mechanics, 15-1 (2) (1981), 185.

23）高橋宏治, 天野利彦, 花折和也, 安藤柱, 高橋文雄, 材料, 58,12 (2009), pp.1030-1036. 